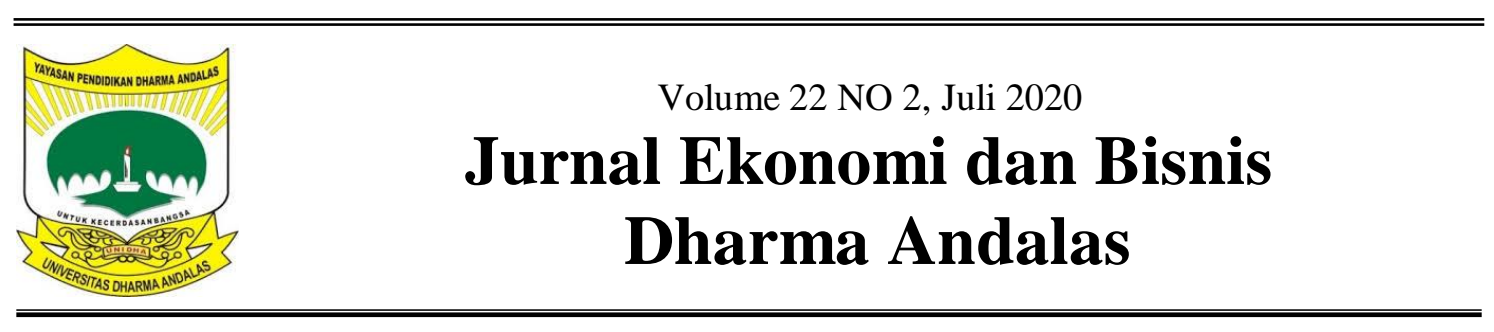

\title{
Pengaruh Seleksi dan Kompetensi Terhadap Prestasi Kerja Karyawan Pada PT.Karya Murni Sentosa Padang
}

\author{
Syahril \\ Fakultas Ekonomi Dan Bisnis Universitas Dharma Andalas \\ syahrilsenyo1967@gmail.com
}

\begin{abstract}
In conducting the selection there are procedures that must be followed by the human resource development team so as not to run away from the actual concept, Because both of these aling related to each other that must be considered by the leadership of the company, because it will have an impact on employee performance at PT, Karya Murni Sentosa. The problem faced by PT, Karya Murni Sentosa is the low work performance of its employees, because they do not have the competence in accordance with their fields this is caused by errors in employee selection. The selection system that has been carried out so far still uses a closed system even though it has received employees at the job fair, but during the interview it still chooses its relatives. In this study, of the two independent variables studied, both of these variables both partially and simultaneously have a significant effect on employee performance at PT. Karya Murni Sentosa namely selection and competency variables. The population in this study was 18 employees, where all populations were directly sampled using total sampling techniques.
\end{abstract}

Keywords: selection, competency and job performance

\begin{abstract}
ABSTRAK
Dalam melakukan seleksi ada tata cara yang harus diikuti oleh tim pengembangan sumber daya manusia agar tidak lari dari konsep yang sebenarnya, Sebab kedua hal ini saling terkait satu sama lain yang harus diperhatikan oleh pimpinan perusahaan, sebab akan berdampak terhadap prestasi kerja karyawan pada PT, Karya Murni Sentosa. Adapun masalah yang dihadapi oleh PT, Karya Murni Sentosa ini adalah masih rendahnya prestasi kerja karyawannya, karena tidak memiliki kompetensi sesuai dengan bidangnya hal ini disebabkan oleh kesalahan dalam melakukan seleksi karyawan. Sistim seleksi yang dilakukan selama ini masih memakai sistim tertutup walaupun pernah melakukan penerimaan karyawan di job fair,tapi saat wawancara masih memilih kerabatnya. Dalam penelitian ini dari kedua variabel bebas yang yang diteliti dimana kedua variabel tersebut baik secara parsial maupun secara simultan berpengaruh signifikan terhadap prestasi kerja karyawan pada PT. Karya Murni Sentosa yaitu variabel seleksi dan variabel kompetensi. Adapun jumlah populasi dalam penelitian ini adalah 18 orang karyawan, dimana semua populai langsung dijadikan sampel dengan menggunakan teknik pengambilan sampel total sampling.
\end{abstract}

Kata Kunci : seleksi, kompetensi dan prestasi kerja.

\section{PENDAHULUAN}

Dalam memilih karyawan sesuai dengan yang kita inginkan maka perusahaan harus melakukan seleksi dengan benar dan melakukan seleksi secara terbuka pada job fair. Seleksi merupakan proses pemilihan individuindividu yang memiliki kualifikasi yang relevan untuk mengisi posisi dalam suatu organisasi.Tanpa para tenaga kerja yang memenuhi persyaratan, sebuah organisasi berada dalam posisi yang 
lebih buruk untuk berhasil.

Seleksi lebih dari sekedar pemilihan orang terbaik dari yang tersedia, namun selesksi adalah mendapatkan karyawan yang sesuai dengan yang dibutuhkan dari sekumpulan pengetahuan, keahlian, dan kemampuan yang sesuai dan merupakan satu paket yang terdapat pada manusia merupakan untuk memperoleh kecocokan antara apa yang dapat dilakukan oleh pelamar dan apa yang dibutuhkan oleh organisasi.

Tujuan melakukan seleksi ini untuk mendapatkan kompetensi dari sumberdaya manusia yang relevan dengan pekerjaannya. Karena dengan kompetensi yang tepat akan dapat menignkatkan produktivitas perusahaan dan dapat meningkatkan prestasi kerja dari karyawan itu sendiri. Untuk itu perlu dilakukan seleksi yang tepat untuk mendapatkan kompetensi sesuai dengan skill yang dimiliki oleh tenaga kerja yang telah diterima.

Kompetensi yang baik dan keputusan yang benar dari penerimaan karyawan baru merupakan bagian penting dari kesuksesan menajemen sumber daya manusia. Beberapa orang akan berargumen bahwa keputusan keputusan ini merupakan bagian yang terpenting. Penigkatan kinerja karyawan bagi perusahaan dapat berasal dari perubahan dalam rencana pemberian insentif, peningkatan pelatihan, atau desain pekerjaan yang lebih baik, tetapi jika perusahaan tidak memiliki orang orang yang dibutuhkan dengan pengetahuan, keahlian, dan kemampuan yang sesuai pada posisinya, perubahanperubahan tersebut mungkin tidak membawa dampak yang besar terhadap kinerja karyawan. Pelatihan yang terbaikpun tidak dapat membuat seseorang dengan sedikit bakat yang dimilikinya mampu melakukan pekerjaan tertentu dengan baik dan menikmatinya.
Agar kompetensi ini bermanfaat begi perusahaan maka, tempatkanlah karyawan tersebut sesuai dengan kompetensi yang dimiliki tenaga kerja. Penempatan tenaga kerja yang tepat pada posisi yang tepat, bukan saja menjadi idaman perusahaan, tetapi juga menjadi keinginan para tenaga kerja.. Dengan demikian para tenaga kerja yang bersangkutan dapat mengetahui ruang lingkup pekerjaan yang dibebankan. Penempatan tenaga kerja adalah suatu proses pemberian tugas dan pekerjaan kepada tenaga kerja yang lulus dalam seleksi untuk dilaksanakan kontinuitas dengan wewenang dan tanggung jawab sebesar posisi dan komposisi yang ditetapkan, serta mampu mempertanggungjawabkan segala resiko dan kemungkinan yang terjadi atas tugas dan pekerjaan, wewenang dan tanggug jawab tersebut. Wewenang dan tugas yang diberikan tidaklah bersifat mutlak, tetapi sebesar bagian yang telah ditentukan.

Seleksi dan kompetensi yang efektif akan menghindari terjadinya kesalahan dalam penerimaan karyawan, dengan demikian karyawan yang diterima akan sesuai dengan yang dibutuhkan perusahaan sehingga tidak terjadi kesalahan dalam pemberian uraian tugas oleh perusahaan.

Salah satu perusahaan yang menjadikan seleksi dan kompetensi sebagai ajang pencarian tenaga kerja yang baru dan berkualitas untuk ditempatkan pada posisi yang tepat adalah PT. Karya Murni Sentosa , dimana perusahaan yang bergerak dibidang bengkel asuransi yang bekerja sama dengan PT. Adira cabang Padang sangat perlu memperhatikan sumber daya manusianya agar apa yang diinginkan oleh perusahaan dapat tercapai dengan baik. PT. Karya Murni Sentosa sudah melakukan sistim seleksi secara terbuka, sehingga kompetensi karyawan yang diinginkan sudah 
didapatkan, namun karyawan ingin posisi yang baik walaupun tidak sesuai dengan tingkat pendidikannya dan kemampuannya. Hal ini menyebabkan kinerja karyawan menjadi jelek dan berdampak terhadap penerimaan profitabilitas perusahaan.

Untuk mengatasi hal ini, sehingga perusahaan mengambil kebijakan baru yaitu seleksi dan kompetensi yang tepat pada pekerjaan yang sesuai harapan agar tercapainya tujuan yang diinginkan. Untuk itu perusahaan melakukan seleksi terbuka pada job fair agar diketahui oleh umum dengan memprioritaskan tingkat pendidikan dan keahlian.

Sistem seleksi dan kompetensi karyawan yang berkualitas akan berdampak terhadap kinerja perusahaan dalam jangka panjang.

Pada tabel di bawah ini dapat dilihat perkembangan jumlah karyawan pada PT. Karya Murni Sentosa menurut tingkat pendidikan selama 3 tahun terakhir :

Tabel 1

\section{Perkembangan Karyawan PT. Karya} Murni Sentosa

Keadaan Tahun 2017 - 2019

\begin{tabular}{ccccc}
\hline \multirow{2}{*}{ No } & $\begin{array}{c}\text { Tingkat } \\
\text { Pendidikan }\end{array}$ & \multicolumn{3}{c}{ Tahun } \\
\cline { 3 - 5 } & SMP & 1 & $\mathbf{2 0 1 8}$ & $\mathbf{2 0 1 9}$ \\
\hline 1 & SMA/SMK & 9 & 9 & 9 \\
2 & DIII & 3 & 3 & 3 \\
3 & S1 & 5 & 5 & 5 \\
4 & & 18 & 18 & 18 \\
\hline Jumalah & & &
\end{tabular}

Dari tabel 1 diatas dapat lihat bahwa pendidikan tertinggi yang dimiliki oleh karyawan PT. Karya Murni Sentosa adalah berpendidikan S1 sebanyak 5 orang sedangkan yang lainnya berpendidikan D.3 sebanyak 3 orang dan sekolah menengah baik tingkat pertama maupun tingkat atas sebanyak 10 orang, sedangkan yang terbanyak adalah karyawan yang berpendidikan SMA atau SMK.
Adapun rumusan masalah dalam penelitian ini adalah sejauh mana proses seleksi berpengaruh signifikan terhadap prestasi kerja karyawan pada PT. Karya Murni Sentosa ,sejauh mana kompetensi berpengaruh signifikan terhadap prestasi kerja karyawan pada PT Karya Murni Sentosa Dan Sejauh mana proses seleksi dan Kompetensi berpenagruh signifikan terhadap Prestasi kerja karyawan pada PT. Karya Murni Sentosa Selanjutnya tujuan dari penelitian ini adalah.untuk mengetahui sejauh mana proses seleksi berpengaruh signifikan terhadap prestasi kerja karyawan pada PT. Karya Murni Sentosa ,Untuk mengetahui sejauh mana Kompetensi berpengaruh signifikan terhadap prestasi kerja karyawan pada PT . Karya Murni Sentosa dan untuk mengetahui sejauh mana proses seleksi dan Kompetensi berpenagruh signifikan terhadap prestasi karyawan pada PT. Karya Murni Sentosa.

Sedangkan manfaat penelitian ini adalah bagi PT Karya Murni Sentosa , semoga dapat menambah informasi dalam melakukan seleksi dan mendapatkan Kompetensi karyawan agar dapat meningkatkan prestasi kerja karyawan sesuai dengan yang diharapkan. Dan bagi penulis, penelitian ini sangat bermanfaat untuk menambah wawasan dan pengembangan ilmiah.

\section{Pengertian Seleksi}

Seleksi dilakukan setelah dilaksanakanya proses rekrutmen karyawan, maka tindakan selanjutnya adalah melakukan seleksi pada setiap lamaran yang masuk. Kegiatan seleksi ini akan menyaring dan memilih pelamar yang memenuhi syarat -syarat yang telah ditentukan. Terlebih dahulu penulis mengemukakan beberapa pengertian seleksi menurut para ahli. Menurut Hadi Poerwono (2003:30) memberikan bahasan sebagai berikut : Seleksi personalia adalah cara untuk mendapatkan karyawan yang paling mendekati syarat - syarat yang telah 
ditetapkan untuk tiap - tiap tugas dan mendekati tujuan tercapainya the rihgt man in the right place"

Dan menurut Faustino Cardoso Gomes (1995 : 30) "Seleksi adalah merupakan serangkaian langkah kegiatan yang dilaksanakan untuk memutuskan apakah seseorang pelamar diterima atau ditolak" sedangkan menurut Soekidjo Notoatmidjo (2003 : 18) mengemukakan "Proses seleksi adalah serangkaian kegiatan yang digunakan untuk memutuskan apakah pelamar diterima atau ditolak"

Jadi dapat ditarik kesimpulan dari beberapa pengertian diatas, bahwa seleksi adalah mencari calon-calon yang memenuhi syarat - syarat yang akan diterima dan ditempatkan pada posisi jabatan yang tepat pula sehingga akan terwujud prinsip "'The right man the right job'.

Dari pendapat - pendapat diatas dapat diketahui bahwa tujuan diadakanya seleksi adalah sebagai berikut; (1) Untuk mendapatkan karyawan yang berkualitas serta sesuai dengan jabatan yang didudukinya; (2) Untuk mengukur kemampuan pelamar dalam melakukan pekerjaan tertentu.

Proses seleksi pemilihan calon karyawan yang akan bekerja di suatu perusahaan memerlukan orang - orang dengan kriteria -kriteria yang telah ditetapkan sebelumnya. Didalam pemilihan, ada beberapa kualifilasi yang menunjang tercapainya seleksi yang harus tercantum dalam job specifikation yaitu .

a. Jenis kelamin

b. Usia Pendidikan formal (kalau perlu disertai pengalaman)

c. Kemampuan khusus sehubungan dengan pekerjaanya seperti : daya ingat, kecepetan reaksi pandangan.

d. Kualifikasi emosi seperti : stabilitas emosi. Ini perlu untuk menempatkan karyawan yang tidak lekas lelah, bosan dalam melaksanakan pekerjaanya.

e. Syarat - syarat kesehatan dan kondisi tubuh.

\section{Pada umumnya tahap - tahap proses seleksi terdiri :}

1. Mengisi formulir: jika seseorang pelamar sudah memenuhi persyaratan pekerjaan, langkah berikutnya adalah pengisian formulir lamaran yang merupakan catatan formal lamaran seseorang terdiri dari nama, umur, ras, dan karakteristik fisik, riwayat pekerjaan, dan pendidikan.

2. Wawancara : adalah percakapan yang umumnya dilakukan antara dua orang dengan maksud tertentu. Sedangkan wawancara pekerjaan adalah percakapan formal yang dilakukan untuk mengevaluasi kemungkinan diterimanya/ditolaknya pelamar.

\section{Tujuan dari pada wawancara} adalah sebagai berikut :

a) Untuk memperoleh informasi dan menentukan apakah kecocokan dengan jod yang ditawarkan.

b) Memberikan informasi mengenai perusahaan, pekerjaan serta orang orang yang ada dalam lingkungan, sehingga pelamar dapat mengambil keputusan apakah menerima/menolak pekerjaan.

3. Tes Seleksi, Digunakan untuk menilai kecocokan pelamar dengan persyaratan seperti keahlian, kemampuan, sikap, minat, dan kepribadian karena informasi yang diberikan relatuf objektif jika dibandingkan dengan wawancara yang tidak terstandarrisasi dan tidak mencakup keahlian dan informasi yang diberikan.

\section{Jenis - Jenis Seleksi Yang}

\section{Digunakan}

a. Test psikologi untuk mengetahui kepribadian sipelamar

b. Test pengetahuan. Akan memberikan informasi mengenai pengetahuan yang dimiliki pelamar sesuai dengan 
pekerjaann yang ditawarkan. Hasil test lebih dapat diandalkan dibandingkan dengan test psikologis.

c. Melaksanakan pekerjaan dimana kelak ditempatkan.

d. Test pencapaian. Manilai smapai setingkat mana seseorang telah belajar, dapat dijadikan indikator untuk menentukan bisa/tidaknya dalam melaksanakan pekerjaan.

e. Test bakat. Untuk mengetahui seseorang dapat dilatih sesuai dengan potensi dan kemampuan yang dimiliki yang bisa diperoleh dengan mengikuti magang, pengalaman dan pelatihan.

\section{Metode Seleksi}

Metode seleksi yang dipakai dalam pelaksanaan seleksi ada dua cara yaitu :

1. Metode Successive huddles

Yaitu metode seleksi berdasarkan, bahwa bila setiap tahap dilalui pelamar tersebut, tidak diperkenankan melanjudkan tahap berikutnya.

2. Metode Compensatory Approach Yaitu metode seleksi dimana pelamar mengikuti beberapa penjumlahan testing tersebut dinilai apakah dari pelamar mencapai standar/tidak.

\section{Faktor - faktor Yang Mempengaruhi Seleksi}

Menurut Garry Desler (1997 : 171) adapun faktor - faktor yang mempengaruhi seleksi adalah sebagai berikut :

1. Faktor geografi

2. Faktor pendidikan atau latar belakang teknis yang dipersyaratkan

3. Faktor perkembangan industri

4. Faktor persyaratan kerja khususnya lisensi dan sertifikat

5. Faktor keanggotaan

\section{Indikator Seleksi}

Seleksi merupakan proses pemilihan dari sekolompok pelamar yang paling memenuhi kriteria seleksi untuk posisi yang teredia didalam perusahaan.Adapun indikator seleksi antara lain: a) Seleksi dilakukan setelah rektuitmen

b) Seleksi dilakukan secara

c) efisien dan efektif

d) tes potensi akademik

e) Tes kesehatan

f) Tes psikologis dalam seleksi

g) Tes wawancara

h) Seleski mempengaruhi peningkatan produktivitas

\section{Pengertian Kompetensi}

Menurut Muhaimin (2004:151)

kompetensi adalah seperangkat tindakan intelegen penuh tanggung jawab yang harus dimiliki seseorang sebagai syarat untuk dianggap mampu melaksanakan tugas-tugas dalam bidang pekerjaan tertentu

Selanjutnya menurut Sofo (1999:123) mengemukakan " $A$ competency is composed of skill, knowledge, and attitude, but in particular the consistent applications of those skill, knowledge, and attitude to the standard of performance required in employment". Dengan kata lain kompetensi tidak hanya mengandung pengetahuan, keterampilan dan sikap, namun yang penting adalah penerapan dari pengetahuan, keterampilan, dan sikap yang diperlukan tersebut dalam pekerjaan.

Begitu juga menurut Spencer \& Spencer (1993:9) mengatakan "Competency is underlaying characteristic of an individual that is causally related to criterion reference effective and/ or superior performance in a job or situation". Jadi kompetensi adalah karakteristik dasar seseorang yang berkaitan dengan kinerja berkriteria efektif dan atau unggul dalam suatu pekerjaan dan situasi tertentu.

Berdasarkan uraian diatas kompetensi dapat diartikan sebagai penguasaan terhadap pengetahuan, keterampilan, nilai dan sikap yang direfleksikan dalam kebiasaan berfikir dan bertindak seorang karyawan dalam bekerja. Dengan demikian kompetensi 
yang dimiliki oleh setiap karyawab akan menunjukan kualitas karyawan tersebut dalam meningkatkan produktifitas kerja. Kompetensi terus akan terwujud dalam bentuk penguasaan pengetahuan, keterampilan, maupun sikap professional dalam memajukan karyawan tersebut.

Diyakini Robotham (1996:27), kompetensi yang diperlukan oleh seseorang tersebut dapat diperoleh baik melalui pendidikan formal maupun pengalaman.

Unsur-unsur atau Elemen Kompetensi

Stephen P. Becker dan Jack Gordon mengemukakan beberapa unsur atau elemen yang terkandung dalam konsep kompetensi di antaranya:

a. Pengetahuan (knowledge), yaitu kesadaran dalam bidang kognitif. Misalnya: seorang guru mengetahui bagaimana melaksanakan kegiatan identifikasi, penyuluhan dan proses pembelajaran terhadap warga belajar.

b. Pemahaman (understanding) yaitu kedalaman ranah kognitif dan afektif yang dimiliki oleh siswa. Misalnya: seorang guru yang akan melaksanakan kegiatan harus memiliki pemahaman yang baik tentang keadaan dan kondisi warga belajar di lapangan sehingga dapat melaksanakan program kegiatan secara baik dan afektif.

c. Kemampuan (skill), yaitu sesuatu yang dimiliki oleh individu untuk melakukan tugas atau pekerjaan yang dibebankan kepadanya. Misalnya: kemampuan yang dimiliki oleh guru untuk menyusun alat peraga pendidikan secara sederhana.

d. Nilai (value), yaitu suatu standar perilaku yang diyakini dan secara psikologis telah menyatu dalam diri individu.

e. Sikap (attitude), yaitu suatu perasaan (senang tidak senang, suka tidak suka) atau reaksi terhadap suatu rangsangan yang datang dari luar. f. Minat (interest), ialah keadaan yang mendasari motivasi individu, keinginan yang berkelanjutan, dan orientasi psikologis. Misalnya: guru yang baik selalu tertarik dengan warga belajar dalam hal membina dan memotivasi supaya dapat belajar sebagaimana yang diharapkan (dalam Majid dan Dian Andayani, 2004: 5152).

Berdasarkan pendapat-pendapat di atas dapat disimpulkan bahwa kompetensi adalah sebuah pernyataan terhadap apa yang harus dilakukan seseorang di tempat kerja untuk menunjukan pengetahuannya, keterampilannya, dan sikap sesuai dengan standar yang dipersyaratkan, di samping itu juga harus mencakup lima dimensi dari kompetensi.

Disamping itu kompetensi juga berkaitan dengan kepribadian seseorang sesuai dengan pendapat ( Syah, 2006 : 225 ) dengan istilah - istilah sebagai berikut :

a. Personality (kepribadian): penggambaran tingkah laku secara deskriptif tanpa memberi nilai (devaluative).

b. Character (karakter): penggambaran tingkah laku dengan menonjolkan nilai (benar-salah, baik-buruk) baik secara eksplisit maupun implisit.

c. Disposition (watak): karakter yang telah lama dimiliki dan sampai sekarang belum berubah.

d. Temperament (temperamen): kepribadian yang berkaitan erat dengan pola determinan biologik atau fisiologik, disposisi hereditas.

e. Traits (sifat): respon yang senada (sama) terhadap sekelompok stimuli yang mirip, berlangsung dalam kurun waktu yang (relatif) lama.

f. Type-attribute (ciri): mirip dengan sifat, namun dalam kelompok stimuli yang lebih terbatas. 
g. Habit: kebiasaan respon yang sama cenderung berulang untuk stimulus yang sama pula.

Kompetensi kepribadian adalah salah satu kemampuan yang sangat dibutuhkan karyawan dalam melaksanakan tugas-tugasnya. Seorang karyawan yang memiliki kompetensi kepribadian meniscayakan dirinya memiliki kemampuan dalam melakukan pekerjaannya dengan baik, sehingga ia pun akan selalu memiliki sikap optimis dalam melakukan pekerjaannya, serta akan cepat dan tepat dalam mengambil keputusan-keputusan strategis yang akan mendukung kinerjanya.

\section{Indikator Kompetensi}

Menurut Mulyasa, 2009 : 75 adapun indicator kompetensi adalah sebagai berikut :
a. Seseorang harus memiliki keterampilan ( Skill)
b. Memiliki Pengetahuan (Knowledge)
c. Pemaaf
d. Kreatif
e. Empati
f. Memiliki kemampuan ( Ability )
g. Disiplin
h. Ikhlas
i. Berani
j. Rendah hati
k. Adil
1. Jujur
m. Berwibawa

\section{Faktor-Faktor yang mempengaruhi Kompetensi Kepribadian}

Menurut Monks, dkk. (1990), ada beberapa faktor yang mempengaruhi kompetensi interpersonal, yaitu:

a. Umur atau kematangan sesorang. Konformisme semakin besar dengan bertambahnya usia.

b. Status ekonomi akan mempengaruhi kepribadian karena bila sesoorang memiliki status ekonomi yang mapan maka rasa nyaman dan percaya diri akan tumbuh.

c. Motivasi diri. Adanya dorongan untuk memiliki status seperti inilah yang akan menyebabkan seseorang berinteraksi dengan orang lain, individu akan menemukan kekuatan dalam mempertahankan dirinya di dalam lingkungan sosial.

d. Keadaan keluarga dan lingkungan. Suasana rumah yang sangat tidak menyenangkan dan tekanan dari orang tua akan membentuk sebuah karakter individu dalam berinteraksi dengan lingkungan.

e. Pendidikan. Pendidikan yang tinggi adalah salah satu faktor dalam interaksi teman sebaya karena orang yang berpendidikan tinggi mempunyai wawasan dan pengetahuan yang luas, yang mendukung dalam pergaulannya.

\section{Pengertian Prestasi Kerja}

Menurut Handoko (2000)

penilaian prestasi kerja adalah proses melalui dimana organisasi-organisasi mengevaluasi atau menilai prestasi kerja karyawan. Kegiatan ini dapat memperbaiki keputusan-keputusan personalia, memberikan umpan balik dan mempengaruhi kerja para karyawan tentang pelaksanaan kerja mereka. Sedangkan menurut Bernardin dan Rusel dalarn Achmad. S. Rucky (2002:15) memberikan definisi tentang prestasi adalah catatan tentang hasil-hasil yang diperoleh dari fungsi-fungsi pekerjaan tertentu atau kegiatan tertentu selama kurun waktu tertentu.

Faktor-faktor yang mempengaruhi prestasi kerja adalah :

a. Faktor Kemampuan

Secara psikologis, kemampuan pegawai terdiri dari kemampuan potensi (IQ) dan kemampuan realitas (knowledge dan skill) artinya pegawai yang memiliki IQ diatas rata-rata (IQ 110-120) dengan pendidikan yang memadai untuk jabatannya dan terampil dalam mengerjakan pekerjaan sehari-hari, sehingga memudahkan pencapaian kinerja.

b. Faktor Motivasi 
Motivasi terbentuk dari sikap (attitude) seseorang pegawai dalam menghadapi situasi (situation) kerja. Motivasi merupakan kondisi yang menggerakkan diri pegawai yang terarah untuk mencapai tujuan organisasi. 6 (enam) karakteristik pegawai yang memiliki motif untuk berprestasi tinggi (Anwar, 2002) :

- Memiliki tanggujawab pribadi yang tinggi

- Berani mengambil resiko

- Memiliki tujuan yang realistis

- Memiliki rencana kerja yang menyeluruh dan berjuang untuk merealisasi tujuannya

- Memanfaatkan umpan balik (feed back) yang konkret dalam seluruh kegiatan kerja yang dilakukannya

- Mencari kesempatan untuk merealisasikan rencana yang telah diprogramkan.

\section{Tujuan dan Kegunaan Prestasi Kerja}

Penilaian prestasi kerja karyawan

berguna untuk perusahaan serta bermanfaat bagi karyawan. Menurut Hasibuan (2001) tujuan dan kegunaan prestasi kerja adalah :

1. Sebagai dasar dalam pengambilan keputusan yang digunakan untuk promosi, demosi, pemberhentian dan penetapan besarnya balas jasa

2. Untuk mengukur prestasi kerja, yaitu sejauh mana karyawan bisa sukses dalam pekerjaannya

3. Sebagai dasar untuk mengevaluasi efektivitas seluruh kegiatan didalam perusahaan

4. Sebagai dasar untuk mengevaluasi program pelatihan dan keefektifan jadwal kerja, metode kerja, struktur organisasi, gaya pengawasan, kondisi kerja dan peralatan kerja

5. Sebagai indikator untuk menentukan kebutuhan akan latihan bagi karyawan yang berada dalam organisasi

6. Sebagai dasar untuk meningkatkan motivasi kerja karyawan sehingga dicapai tujuan untuk mendapatkan performance kerja yang baik

7. Sebagai alat untuk mendorong atau membiasakan para atasan untuk mengobservasikan prilaku bawahan supaya diketahui minat dan kebutuhannya

8. Sebagai alat untuk melihat kekurangan atau kelemahan dimasa lalu dan meningkatkan kemampuan karyawan selanjutnya

9. Sebagai alat untuk mengidentifikasi kelemahan personel sehingga bisa menjadi bahan pertimbangan diikutsertakan dalam program pelatihan

10.Sebagai dasar untuk memperbaiki atau mengembangkan kecakapan karyawan

11.Sebagai dasar untuk memperbaiki dan mengembangkan uraian pekerjaan

\section{Unsur-unsur yang Dinilai}

Menurut Hasibuan (2001) unsur-unsur yang dinilai meliputi :

1. Kesetiaan : penilai mengukur kesetiaan karyawan terhadap pekerjaannya, jabatannya dan organisasi

2. Prestasi kerja : penilai menilai hasil kerja baik kualitas dan kuantitas yang dapat digunakan karyawan tersebut dari uraian pekerjaannya

3. Kejujuran : penilai menilai kejujuran dalam melaksanakan tugas-tugasnya memenuhi perjanjian bagi dirinya sendiri maupun orang lain

4. Kedisiplinan : penilai menilai kedisiplinan dalam mematuhi aturanaturan yang ada

5. Kreativitas : penilai menilai kemampuan karyawan dalam mengembangkan kreativitasnya untuk menyelesaikan tugasnya

6. Kerjasama : penilai menilai kesediaan karyawan berpartisipasi dan bekerjasama dengan karyawan lainnya

7. Kepemimpinan : penilai menilai kemampuan untuk memimpin, mempunyai pengaruh yang kuat dan 
dapat memotivasi orang lain atau bawahannya untuk bekerja efektif

8. Kepribadian : penilai menilai karyawan dari sikap prilaku, kesopanan dan penampilan

9. Prakarsa : penilai menilai kemampuan berpikir orisinil dan berdasarkan inisiatif sendiri untuk menyelesaikan masalah

10. Kecakapan : penilai menilai kecakapan karyawan dalam menyatukan dan menyelaraskan berbagai macam elemen dalam penyusunan kebijaksanaan

11. Tanggung jawab : penilai menilai kesediaan karyawan dalam mempertanggungjawabkan

kebijaksanaannya, pekerjaan dan hasil kerjanya, sarana dan prasarana yang dipergunakannya serta prilaku kerjanya.

Unsur prestasi kerja karyawan yang akan dinilai oleh setiap organisasi atau perusahaan tidak selalu sama, tetapi pada dasarnya unsur-unsur yang dinilai itu mencakup seperti hal-hal diatas.

\section{Kerangka Konseptual}

a) Pengaruh seleksi terhadap prestasi kerja karyawan

- Jika seleksi tepat maka akan sangat berpengaruh terhadap prestasi kerja karyawan.

- Seleksi yang baik dan benar memacu terjadinya prestasi kerja yang baik

- Seleksi sangat berpengaruh pada prestasi kerja karyawan jika seleksi sngat adil dan seimbang.

- Seleksi yang sekarang ini dilakukan menunjang terjadinya prestasi kerja karena system kekeluargaan tidak diprioritaskan lg dalam seleksi.

b)Pengaruh Kompetensi Terhadap Prestasi kerja

- Jika karyawan memiliki kompetensi sesuai dengan yang diharapkan maka hal ini akan berpengaruh terhadap prestasi kerja karyawan.

- Jika kompetensi karyawan sesuai dengan keahliannya ini juga akan berpengaruh terhadap prestasi kerja karyawan

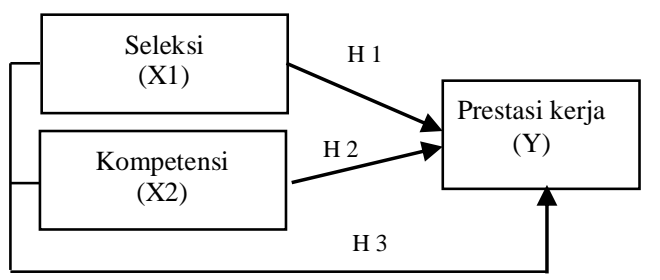

Gambar 1

Kerangka Koseptual Penelitian

\section{Hipotesis}

H1 :Seleksi berpengaruh signifikan terhadap prestasi kerja karyawan pada PT.Karya Murni Sentosa

$\mathrm{H} 2$ :Kompetensi berpengaruh signifikan terhadap prestasi kerja karyawan pada PT. Karya Murni Sentosa

H3 :Seleksi dan Kompetensi berpengaruh signifikan terhadap prestasi kerja karyawan.Pada PT.Karya Murni Sentosa

\section{METODE PENELITIAN}

Populasi yang terdapat dalam penelitian ini adalah seluruh karyawan yang ada pada PT.Karya Murni sentosa yaitu sebanyak 18 orang.

Teknik Sampel yang digunakan adalah total random sampling, yang berarti semua populasi dijadikan sampel karena sampel penelitian ini kecil 18 orang.

\section{Metode Pengumpulan Data}

a. Studi kepustakaan ( library

Research)

b. Riset lapangan ( field Research)

\section{Metode Analisis}

Metode analisa yang digunakan dalam penelitian ini adalah :

a. Metode analisa kualitatif

b. Metode Analisa kuantitatif

Yaitu dengan dengan menggunakan rumus regresi linier berganda

\section{HASIL DAN PEMBAHASAN \\ Hasil Penelitian \\ Uji F Statistik}

Uji $F$ dilakukan untuk menguji secara keseluruhan pengaruh variabel 
bebas terhadap variabel terikat, dengan kriteria pengujian sebagai berikut :

Jika sig. $<\alpha$, maka Ho ditolak dan $\mathrm{Ha}$ diterima. Ini berarti semua variabel independen berpengaruh signifikan terhadap variabel dependen. Dalam penelitian ini didapat hasil uji hipotesis bahwa, semua variabel bebas atau variabel seleksi dan variabel kompetensi berpengaruh signifikan terhadap variabel prestasi kerja secara bersama-sama, karena memiliki tingkat sig. $<\alpha$ yaitu $0,000<0,05$.

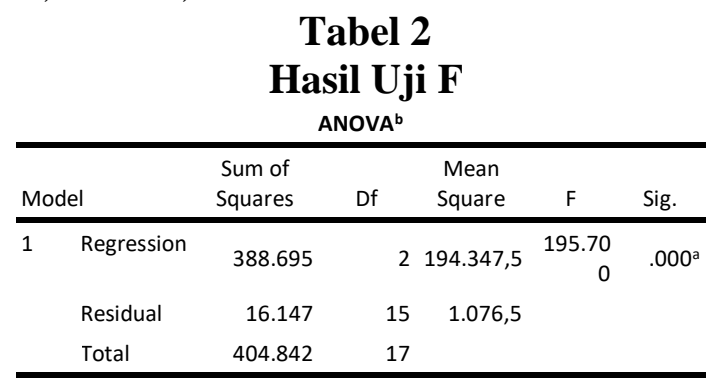

a. Predictors: (Constant), SELEKSI, KOMPETENSI

b. Dependent Variable: PRESTASI KERJA

Berdasarkan tabel 2 dengan uji $\mathrm{F}$ secara bersama-sama variabel bebas terhadap variabel terikat dalam penelitian ini yaitu variable Seleksi dan variabel Kompetensi berpengaruh signifikan terhadap Prestasi kerja pada PT. Karya Murni Sentosa karena memiliki $F_{\text {hit }}>F_{\text {tabel }}$ atau Sig. $<\alpha$ yaitu $0,000<0,05$. Ini berarti seleksi dan kompetensi secara bersama-sama berpengaruh signifikan terhadapa prestasi kerja pada PT. Karya Murni Sentosa.

Pada perusahaan ini seleksi dan kompetensi yang benar dan tepat sangat dibutuhkan sekali, karena sangat berhubungan dengan masalah teknis. Sebbab salah sedikit saja fatal akibatnya oleh sebab itu para karyawan bekerja sangat hati-hati.

\section{Uji t Statistik}

Tabel 3 merupakan hasil regresi variabel penelitian. Hasil tersebut ditunjukkan sebagai berikut:
Tabel 3

Hasil Regresi Variabel Penelitian

\begin{tabular}{|c|c|c|c|c|c|c|}
\hline \multirow{2}{*}{\multicolumn{2}{|c|}{ Model }} & \multicolumn{2}{|c|}{$\begin{array}{l}\text { Unstandardized } \\
\text { Coefficients }\end{array}$} & \multirow{2}{*}{$\frac{\begin{array}{c}\text { Standardized } \\
\text { Coefficients }\end{array}}{\text { Beta }}$} & \multirow[b]{2}{*}{$\mathrm{t}$} & \multirow[b]{2}{*}{ Sig. } \\
\hline & & B & Std. Error & & & \\
\hline \multirow[t]{3}{*}{1} & (Constant) & 13.563 & 2.080 & & 3.849 & .000 \\
\hline & Seleksi & .643 & .895 & .748 & 6.023 & .004 \\
\hline & Kompetensi & .679 & .918 & .769 & 7.156 & .002 \\
\hline
\end{tabular}

a. Dependent Variable: Prestasi Kerja

Berdasarkan tabel 3 diatas, dapat dijelaskan bahwa, variabel Seleksi berpengaruh signifikan terhadap variabel prestasi kerja pada PT. Karya Murni Sentosa dengan koefisien regresi sebesar 0,643 ini berarti bahwa jika ditingkatkan seleksi oleh PT.Karya Murni Sentosa sebesar satu-satuan maka dapat meningkatkan prestasi kerja sebesar 0,643. Sedangkan variabel Kompetensi juga berpengaruh signifikan terhadap prestasi kerja pada PT.Karya Murni Sentosa, karena memiliki koefisien regresi yaitu 0,679 ini berarti bahwa jika kompetensi karyawan meningkat sebesar satu-satuan maka kompetensi juga dapat meningkatkan prestasi kerja karyawan pada PT. Karya Murni Sentosa sebesar 0,679 .

Dengan demikian persamaan regresi dari pengaruh variabel independen terhadap variabel dependen adalah sebagai berikut :

$$
Y=13.563+0,643 X 1+0,679 X 2
$$

Jika seleksi pada PT Karya Murni Sentosa ditingkatkan dengan cara melalukan sistim seleksi secara terbuka, maka PT.Karya Murni Sentosa akan mendapatkan karyawan yang kapabel dan memiliki kompetensi sesuai dengan yang diharapkan. Begitu juga dengan kompetensi jika PT, Karya Murni Sentosa senantiasa memberikan pelatihan-pelatiahn kepada karyawannya, maka karyawan tersebut akan memiliki kompetensi yang lebih baik dan memiliki disiplin yang tinggi. 
Pembahasan

Dari hasil uji hipotesis secara parsial didapat hasil bahwa variabel seleksi berpengaruh signifikan terhadap variabel prestasi kerja di PT. Karya Murni Senotasa ini berarti seleksi yang dilakukan oleh PT. Karya Murni Sentosa sudah sesuai dengan ketentuan yang berlaku yaitu dengan cara terbuka di job fair dengan demikian perusahaan dapat memilih pelamar yang banyak mendaftar sehingga perusahaan betul-betul dapat melakukan seleksi dengan baik dan tepat. Hal ini tentu dapat memberikan kontribusi yang berarti terhadap prestasi kerja karyawan di PT. Karya Murni Sentosa . Disamping itu dengan melakukan seleksi yang benar akan dapat meningkatkan produktivitas yang tinggi. Hal ini tentu juga akan meningkatkan profitabilitas perusahaan sesuai dengan yang diharapkan.

Begitu juga dengan variabel kompetensi juga berpengaruh signifikan terhadap variabel prestasi kerja di PT. Karya Murni Sentosa ini berarti kompetensi yang dilakukan oleh PT. Karya Murni Sentosa sudah sesuai dengan latar belakang pendidikan dan keahlian yang dimiliki oleh karyawan, sehingga hal ini dapat meningkatkan prestsi kerja bagi karyawan tersebut. Kompetensi yang benar akan dapat memberikan kontribusi yang berarti bagi perusahaan seperti dapat meningkatkan prestasi kerja, dapat menmabah produktivitas dan profitasbilitas serta terbuka peluang untuk pengembangan karier bagi karyawan yang ada di perusahaan atau dalam penelitian ini adalah PT. Karya Murni Sentosa Padang.

Begitu juga berdasarkan uji secara simultan didapat hasil bahwa, kedua variabel seleksi dan variabel kompetensi kedua-duanya berpengaruh signifikan terhadap prestasi kerja pada PT,Karya Murni Sentosa. Hal ini dapat dilihat dari hasil kerja yang dilakukan oleh karyawan PT. Karya Murni Sentosa betul-betul sesuai dengan yang diharapkan oleh konsumen.

Dalam penelitian penulis melihat PT.Karya Murni Sentosa melakukan penilaian dengan baik dan transparan dan tidak ada kecurangan dalam melakukan penilaian tersebut sehingga karyawan akan selalu meningkatkan kinerjanya agar prestasi yang didapat oleh karyawan tersebut bisa dipertahankanya.

\section{SIMPULAN}

Berdasarkan hasil penelitian diatas, selanjudnya penulis menyimpulkan dan memberikan saran saran yang kiranya memberikan manfaat untuk kemajuan perusahaan.

Sistem seleksi yang diterapkan oleh perusahaan PT Karya Murni Sentosa menpunyai hubungan signifikan dengan prestasi kerja karyawan, dengan demikian jika perusahaan melakukan seleksi dengan benar maka akan mewujudkan prestasi kerja yang baik bagi perusahaan.

Sedangkan kompetensi juga berpengaruh signifikan terhadap prestasi kerja pada PT.Karya Murni Sentosa, dengan nilai koefisien regresi yang dapat meningkatkan prestasi kerja pada PT. Karya Murni Sentosa. Hal ini disebabkan oleh pekerjaan yang ada pada PT.Karya Murni Sentosa sangat membutuhkan kompetensi. Dari toeri teori dan dari hasil pegolahan data yang penulis lakukan, maka menunjukkan adanya hubungan atau pengaruh yang positif antara seleksi dengan prestasi kerja.

Berdasarkan kesimpulan yang dibuat, disarankan kepada perusahaan PT.Karya Murni Sentosa agar mempertahankan atau meningkatkan sistem seleksi dan lebih memperhatikan kompetensi yang telah dilaksanakan, karena hal tersebut dapat meningkatkan prestasi kerja kayawan di PT. Karya 
Murni Sentosa.

Berdasarkan beberapa saran yang dapat disampaikan, semoga dapat menjadi bahan pertimbangan demi kelangsungan perusahaan dan meningkatkan prestasi kerja karyawan dimasa yang akan datang.

\section{DAFTAR PUSTAKA}

Abdul, Majid. 2005. Perencanaan Pembelajaran dan

Mengembangkan Standar Kompetensi Guru. Bandung: PT Remaja Rosda Karya.

Arikunto, Suharsini (1991). Manajemen Prestasi Kerja, Yoyakarta : Rajawali

Arikunto, Suharsimi. 2005. Manajemen Penelitian. Jakarta. PT Mahasatya.

Achmad S. Ruky, 2013. Sistem Manajemen Kinerja, Cetakan Ketiga.Jakarta : PT.Gramedia Pustaka Utama.

A.M.P, F.J. Monk, Knoers dan Rahayu, Siti, Psikologi Perkembangan Pengantar dalam Berbagain Bagiannya, (Yogyakarta: Gadjah Mada University, 1994)

A. Anwar, 2002. Evaluasi Kinerja Sumber Daya Manusia. Jakarta: Refika Aditama

Almigo, nuzsep.2007.Hubungan Kerja Dengan Produktifitas Kerja Karyawan (The Relation Between Job Statisfation and The Employes Work Productivity). Palembang : Fakultas Psiokologi Universitas Bina Dharma Palembang

Cardoso, Faustino. 2003. Manajemen Sumberdaya Manusia. Yokyakarta. Andi Yole Yokyakarta

Desler, Gary. 2003. Manajemen Sumberdaya Manusia. Jakarta.Gramedia.

Fillipo, Edwin, B.1987. Manajemen Personalia (Terjemahan Moh.Masud) Edisi ke IV. Jakarta. Erlangga
Handoko,Hani.2000.Manajemen

Personalia dan Sumberdaya

Manusia Yokyakarta.: BPFE.

Hasibuan,Melayu (2001). Manajemen Sumber Daya Manusia, Bumi Aksara-Jakarta.

Mulyasa, E. (2003). Kurikulum Berbasis

Kompetensi:

Konsep,

Karakteristik, dan Implementasi.

Bandung: PT Remaja Rosdakarya

Muhaimin, 2004, Wacana

Pengembangan Pendidikan Islam, Yogyakarta : Pustaka Pelajar.

Sofo. Francesco. (1999). Humen Resource Development, Perspective, Roles and practice Choice. Business and Professional Publishing, Warriewood, NWS

Spencer, Lyle M., Jr \& Signe M.,Spencer (1993). Competency at Work: Model for Superior Performance. John Wiley \& Sons .Inc

Poerwono, Hadi, 2003.Tata Personalia, Edisi ke-III, Jakarta Djambatan

Siagian, Sondang, (2003 ). Manajemen Sumber Daya Manusia, Bumi Aksara- Jakarta.

Syah, Muhibbin. (2000). Psikologi Pendidikan dengan Pendekatan Baru. Bandung: PT Remaja Rosdakarya.

Robbins, S, 2003. Perilaku Organisasi Jilid 1. Jakarta : PT IDEX, Gramedia Group.

Randall S.Schuler, Susan E. Jacson. Terjemahan oleh Dwi Kartini, Manajemen Sumber Daya Manusia. Jakarta : Erlangga.

Umar, Husein . 2005. Riset Sumberdaya Manusia . Jakarta .PT Gramedia Pustaka Utama.

Almigo, nuzsep.2007.Hubungan Kerja Dengan Produktifitas Kerja Karyawan (The Relation Between Job Statisfation and The Employes Work Productivity). Palembang : Fakultas Psiokologi Universitas Bina Dharma Palembang. 
Hasan, igbal, (2002), Pokok - pokok satatistik 2, Bumi Aksara, Jakarta, edisi kedua cetakan pertama. 